\title{
Maternal mortality and social vulnerability in a Northeast State in Brazil: a spatial-temporal approach
}

Elena Maria da Silva Duarte 1

iD https://orcid.org/0000-0002-2651-5956

Érika Tenório dos Santos Alencar 2

iD https://orcid.org/0000-0002-9787-7647

Laura Gabriele Alves da Fonseca 3

https://orcid.org/0000-0001-8631-9116

Sylvia Marques da Silva 4

https://orcid.org/0000-0002-3858-6647

\author{
Michael Ferreira Machado 5 \\ iD https://orcid.org/0000-0001-6538-6408 \\ Maria Deysiane Porto de Araújo 6 \\ (iD) https://orcid.org/0000-0002-1258-0845 \\ Divanise Suruagy Correia 7 \\ https://orcid.org/0000-0001-7293-4169 \\ Carlos Dornels Freire de Souza 8 \\ D https://orcid.org/0000-0001-7995-1893
}

\footnotetext{
1-6,8 Departamento de Medicina. Universidade Federal de Alagoas. Campus Arapiraca. Complexo de Ciências Médicas. Av. Manoel Severino Barbosa, s. n. Bom Sucesso. Arapiraca, AL, Brasil. CEP: 57.309-005 Email: carlos.freire@arapiraca.ufal.br

7 Faculdade de Medicina. Universidade Federal de Alagoas. Campus AC Simões. Maceió, AL, Brasil.
}

\begin{abstract}
Objectives: to analyze the epidemiological profile and the spatial-temporal dynamics on maternal mortality in Alagoas and its relationship with social vulnerability and income inequality.

Methods: a mixed ecological study involving maternal deaths who resided in Alagoas from 1996 to 2016. Sociodemographic variables (age, race/color, education, marital status), clinical (type of obstetric cause, death by category and ICD group) were analyzed, besides the indicators (Maternal Mortality Ratio- MMR, Social Vulnerability Index and Gini Index). For the temporal analysis, we used the inflection point regression model and for the spatial analysis, the local empirical Bayesian model, Moran Global and Local statistics, and the bivariate local spatial autocorrelation analysis.

Results: a total of 586 deaths (47.63/100 thousand live births) were registered, with a trend of MMR growth (APC 2.8\%), with a heterogeneous distribution between health regions and cities. The profile was characterized by the predominance of young, black / mixed skin color women with low schooling. Eight cities were considered priority. There was spatial correlation with the Social Vulnerability Index and income inequality.

Conclusions: identifying priority areas may contribute to planning and targeting interventions.

Key words Maternal mortality, Epidemiology, Social vulnerability
\end{abstract}

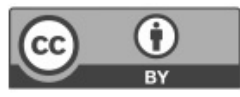




\section{Introduction}

The World Health Organization (WHO) defines a woman's death during pregnancy or up to 42 days after childbirth as maternal death, regardless of duration or location of the pregnancy, due to the cause related to or aggravated by the pregnancy or in relation to by its action, except for accidental or incidental causes. ${ }^{1}$

Maternal mortality is one of the most severe human rights violations, preventable in $92 \%$ of the cases, focusing mainly in developing countries. In Brazil, from 1996 to 2016, there were 35,546 maternal deaths. The Southeast Region occupied the first position in the country with 12,686 cases and the Northeast, in second position with 11,777 deaths. ${ }^{2}$

The Maternal Mortality Ratio (MMR) is an important predictor in the quality of women's healthcare, from prenatal care to puerperium. High MMR are indicative of poor socioeconomic conditions, low level of information and education, family dynamics in which violence is present and, above all, difficulties in accessing quality in the health services. ${ }^{3}$ This predictor is also used for epidemiological, trend and territorial inequality analyzes, and assisting the planning in health policies. 4

In view of the worldwide severity in maternal mortality, the United Nations (UN) developed in 2000, the Millennium Declaration that addresses the "Millennium Development Goals". The fifth objective presents the goals for improving women's health by 2015, including the reduction of maternal mortality by three quarters, as well as universal access to reproductive health. 5 Despite the efforts, Brazil did not achieve this goal, maintaining in 2015 a maternal death rate of 57.59 for every 100 thousand Live Births (LB) ${ }^{6}$

In 2015, the 2030 Agenda for Sustainable Development was released. ${ }^{7}$ It outlined 17 objectives to transform the world by 2030 . The third objective is about health and well-being, with a goal in reducing global Maternal Mortality (MM) in less than 70 deaths per 100 thousand LB, having universal access to sexual and reproductive health services, family planning and the expansion to confront communicable and non-communicable diseases, besides to ensure the investment in policies that permit the reduction of maternal and child mortality, but also to put an end on deaths of preventable obstetric causes. ${ }^{7}$

Healthcare for pregnant women in Brazil gained strength after the implementation of the Sistema Único de Saúde (SUS) (Public Health Service) and the creation of the Estratégia Saúde da Familia (ESF) (Strategy in Family Health) in the 1990s. It was consolidated with the implementation of the Programa de Humanização no Pré-natal e Nascimento (PHPN) (Prenatal and Birth Humanization Program) in 2000, which aimed to reduce maternal and child morbidity and mortality through qualitative improvement in prenatal, childbirth and postpartum care and, later with the implantation of the Rede Cegonha (Stork Network) in 2011, which implemented an organizational model for the maternal and child health network, ensuring prenatal care up to 24 months post-birth. ${ }^{8-9}$

This spatial-temporal type study carried out in Alagoas, over a time span of twenty-one years, may help in understanding the dynamics of maternal mortality in the State, presenting as a possible facilitator for decision-making in health and the adoption of strategies that can reduce maternal mortality in areas of risk. Thus, this study aimed to analyze the epidemiological profile and the spatial-temporal dynamics of maternal mortality in the State of Alagoas (1996-2016) and the relation with social vulnerability and income inequality.

\section{Methods}

This is a mixed ecological study involving maternal deaths in women living in the State of Alagoas, which occurred in the period of 1996 and 2016. A unit of analysis was adopted in the entire State of Alagoas, which is located in the Northeast of Brazil. The State territory is of $27,848,140 \mathrm{~km}^{2}$, comprising 102 cities with an estimated population of $3,322,820$ inhabitants in 2018.10 The State territory is divided into two Health Macro-regions (HM), each with a city pole, and in ten micro-regions. Approximately $95.0 \%$ of Alagoas cities are found to be in a high or extremely high vulnerability. ${ }^{11}$

For the sociodemographic and epidemiological characterization of maternal deaths, the variables age group of the mother, race / skin color, education, marital status, type of obstetric cause (direct, indirect and unspecified), deaths investigated, death according to International Classification of Diseasecategory and group were analyzed, and including MMR. In addition, the Social Vulnerability Index and its three dimensions (education, human capital and income and work) and the Gini Index were included in the study. The Índice de Vulnerabilidade Social (IVS) (Social Vulnerability Index) was prepared by the Instituto de Pesquisas Econômicas Aplicadas (IPEA) (Applied Economic Research Institute) to indicate contexts of vulnera- 
bility and social exclusion in the Brazilian territory. ${ }^{11}$

To calculate the Maternal Mortality Ratio, women's deaths at childbearing age (10 to 49 years) in the group "pregnancy, childbirth and puerperium" from the International Classification of Disease (ICD-10) were considered: i) Pregnancy ending in abortion (O00-008); ii) Edema, proteinuria and hypertensive disorders at pregnancy, childbirth and puerperium (O10-016); iii) Other maternal disorders predominantly related to pregnancy (O20-029); iv) Care given to the mother for reasons related to the fetus and amniotic cavity and for possible problems related to childbirth (O30-048); v) Complications of labor and childbirth (O60-075); vi) Childbirth (O80084); vii) Complications related predominantly to puerperium (O85-092); viii) Other obstetric conditions not classified elsewhere (O95, O98, O99). In addition to ix) Disease caused by HIV (B20-B24); x) Malignant or invasive hydatidiform mole (D39.2); and xi) Postpartum pituitary necrosis (E23.0), as long as the woman is pregnant at the time of death or has been pregnant up to 42 days before death. And the following causes: xii) Puerperal osteomalacia (M83.0); xiii) Obstetric tetanus (A34); and xiv) Mental and behavioral disorders associated with puerperium (F53), in cases where death occurred within 42 days after termination of the pregnancy or in cases of no information at the elapsed time between termination of the pregnancy and death. The ICDs death from any obstetric cause, which occurs more than 42 days, but less than a year, after childbirth (096) and death of sequels from direct obstetric causes (O97) as these are referred to death over 42 days, were excluded from the research.

Death data was extracted from the Sistema de Informações sobre mortalidade (SIM) (Mortality Information System) (http://www2.datasus.gov.br/ DATASUS/index.php?area $=0205 \& i d=6939 \& \mathrm{VObj}=$ http://tabnet.datasus.gov.br/cgi/deftohtm.exe?sim/cn $\mathrm{v} / \mathrm{mat} 10$ ), the data on the number of live births, necessary to calculate MMR, were obtained from the Sistema de Informações de Nascidos Vivos (SINASC) (Live Birth Information System) (http://www2.datasus.gov.br/DATASUS/index.php? area $=0205 \& \mathrm{id}=6936$ ) and the social indicators were obtained from the Atlas de Vulnerabilidade Social (Social Vulnerability Atlas) (http://ivs.ipea.gov.br/index.php/pt/).

After collecting the data, the MMR was calculated using the following equations:

A) Annual MMR: number of maternal deaths on location and year / number of live births on location and year X 100 thousand;
B) Periodic MMR: average of maternal deaths in the period studied and location / number of live births in the middle of the period X 100 thousand;

The statistical treatment was contained in three stages. The first consisted of a descriptive analysis of sociodemographic characteristics, which were presented through absolute number, relative frequency, and MMR.

The second stage was consisted of the trend analysis. For this purpose, the inflection point regression model (Joinpoint regression model) was used. The model tests whether a line of multiple segments is statistically better suited to describe the temporal evolution of the data than a straight line or a line with fewer segments, using the Monte Carlo permutation method. Each inflection point indicates a change in the trend. 12 The Joinpoint allows the classification of the trend into stationary, increasing, or decreasing, allowing the identification of the point at which there is a modification of this trend and the annual percentage variation (APC, Annual Percentage Change). A significance level of $5 \%$ and a 95\% confidence interval (CI95\%) were adopted. In this stage, the Joinpoint Regression Program 4.5.0.1 (National Cancer Institute- USA) was used.

The third stage consisted of spatial modeling. This analysis was divided into two stages. The first was the smoothing of mortality rates with the use of the local empirical Bayesian model. The model restricts the random fluctuation of data, providing greater stability. Its use was justified by the existence of cities with a very reduced population, as well as by the possible fragility of mortality data. This model aims to identify the posterior distribution (unobserved quantities of a given phenomenon) from the application of Bayes' theorem involving sample data (likelihood function) and a set of observed data (a priori distribution). 13

After obtaining the smoothed rates, the spatial dependence was initially assessed by using the Moran Global statistic and the pseudo-significance test. The Moran Index varies between -1 and +1 , with values close to zero indicating spatial randomness; positive values suggest positive spatial autocorrelation and negative values, negative spatial autocorrelation. Once the global spatial dependence was verified, Moran's local statistics (Local Index of Spatial Association - LISA) was applied. From LISA, each city was positioned in a quadrant of the Moran scattering diagram: Q1- high / high (positive values and positive means), Q2- low / low (negative values and negative means), Q3- high / low (positive values and negative means) and Q4- low / high (negative values and positive means). Based on the 
results obtained from the spreading graph of Moran and LISA, thematic maps were made of Moran Map. The Moran Map considers only the areas where Moran indexes are significant $(p<0.05)(19,20)$. Additionally, the analysis of bivariable local spatial autocorrelation between the smoothed MMR and the social indicators was carried out to identify common spatial clusters. 14

For these analyzes, Terra View software 4.2.2 (Instituto Brasileiro de Pesquisas Espaciais- INPE (Brazilian Institute for Space Research), São José dos Campos, SP, Brazil.), GeoDa 1.10 (Center for Spatial Data Science, Computation Institute, The University of Chicago, IL. USA) and QGis 2.14.11 (Open Source Geospatial Foundation- OSGeo, Beaverton, OR. USA) were used. The territorial meshes necessary for making the maps came from Instituto Brasileiro de Geografia e Estatística (IBGE) (Brazilian Institute on Geography and Statistic).

In this study, only secondary data from public domain information systems were used, in which it is impossible to identify individuals. For this reason, authorization from the Research Ethics Committee was waived.

\section{Results}

In the period of 1996 to 2016, 586 maternal deaths were registered in Alagoas, resulting in a mortality rate of 47.63 deaths for every 100 thousand LB. The regression model showed a linear growth trend over the temporal series (APC 2.8\%; CI95\%=0.9 - 4.7; $p<0.001)$. The first macro-region concentrated $62.42 \%(\mathrm{n}=366)$ deaths and demonstrated a tendency for mortality to increase (APC 3.1\%; CI95\% $=1.4$ $4.8 ; p<0.001)$, while the second presented the highest MMR (52.27 / 100 thousand LB), but with a stationary trend. The $3^{\text {rd }}$ and $4^{\text {th }}$ micro-regions were the only ones with an increasing trend (APC 25.0\% and $22.7 \%$, respectively). In contrast, the highest MMR were observed in the $9^{\text {th }}(56.74 / 100$ thousand LB) and the $10^{\text {th }}(59.57 / 100$ thousand LB) microregions, located in the Outback lands in the State (Figure 1).

Of the registered deaths, $36.35 \%(n=213)$ correspond to the age group of 20 to 29 years old (32.44/100 thousand LB), although the highest MMR was registered in the range of 40 to 49 years old (206.52/100 thousand). Mortality in the 15 to 19 age group was the only one with a growing trend (APC 5.4; CI95\%= $2.6-8.2 ; p<0.001$ ). The black and mixed skin color women had the highest mortality rates $(158.21 / 100$ thousand LB and
40.77/100 thousand $\mathrm{LB}$, respectively), with an upward trend in both (APC 21.0\% and 40.6\%, respectively). Low schooling was another characteristic that stood out, with MMR being higher in the population with no schooling (37.84/100 thousand). Additionally, the highest mortality was observed in widowed women (333.89/100 thousand LB) (Table 1).

As for the causes of deaths, the groups "edema, proteinuria and hypertensive disorders in pregnancy, childbirth and puerperium" (26.28\%; $\mathrm{n}=154$ cases; MMR 12.52/100 thousand LB) and "complications at labor and childbirth" stood out $(24.06 \%$; $n=141$ cases; MMR 11.46/100 thousand LB). The categories "eclampsia" $(12.97 \% ; \mathrm{n}=76$ cases; MMR 6.18 / 100 thousand LB) and "other diseases of the mother, classified elsewhere, but which complicate with pregnancy, childbirth and puerperium" (9.22\%; $\mathrm{n}=54$ cases; MMR $4.39 / 100$ thousand) occupied the first positions. Additionally, 87.71\% $(\mathrm{n}=514$ cases) were classified as direct maternal obstetric death (Table 2).

In the spatial modeling in Alagoas, 12 cities did not register any maternal deaths in the studied period. On the other hand, 14 registered ten or more deaths, with a total of 340 cases. Among these, the State capital, Maceió, registered 142 deaths. As for MMR, 11 cities presented rates higher than 100 deaths/100 thousand LB, with emphasis on Maragogi (476.19/100 thousand), Marechal Deodoro (239.18/100 thousand) and Jundiá (200.49/100 thousand). After the correction on the rates performed by the Bayesian model, no city was registered as silent and only one had a rate higher than 100/100 thousand (Jacuípe, 106.60 / 100 thousand LB). In Moran Map, only eight cities were considered priorities: five in the North Coast (Porto Calvo, Maragogi, Jacuípe, Campestre and Jundiá), one in the Scrubland (Arapiraca) and two in the Outback lands (Águabranca and Pariconha) (Figure 2).

In the analysis of bivariate autocorrelation, a spatial relation was observed between MMR and all the analyzed social indicators. As in the univariate analysis, the priority cities were concentrated mainly in the Northeast and in the Outback lands in the State: Two cities for the General Índice de Vulnerabilidade Social (IVS) (Social Vulnerability Index) (in the Northeast of the State), five for the Urban Infrastructure of the IVS (in the Northeast), seven for the Human Capital of the IVS (five in the Northeast and two in the Outback lands), 12 for the Income and Work of the IVS (one in the Scrubland and 11 in the Outback lands) and ten for the Gini Index (three in the Scrubland and seven in the Outback lands) (Figure 3). 


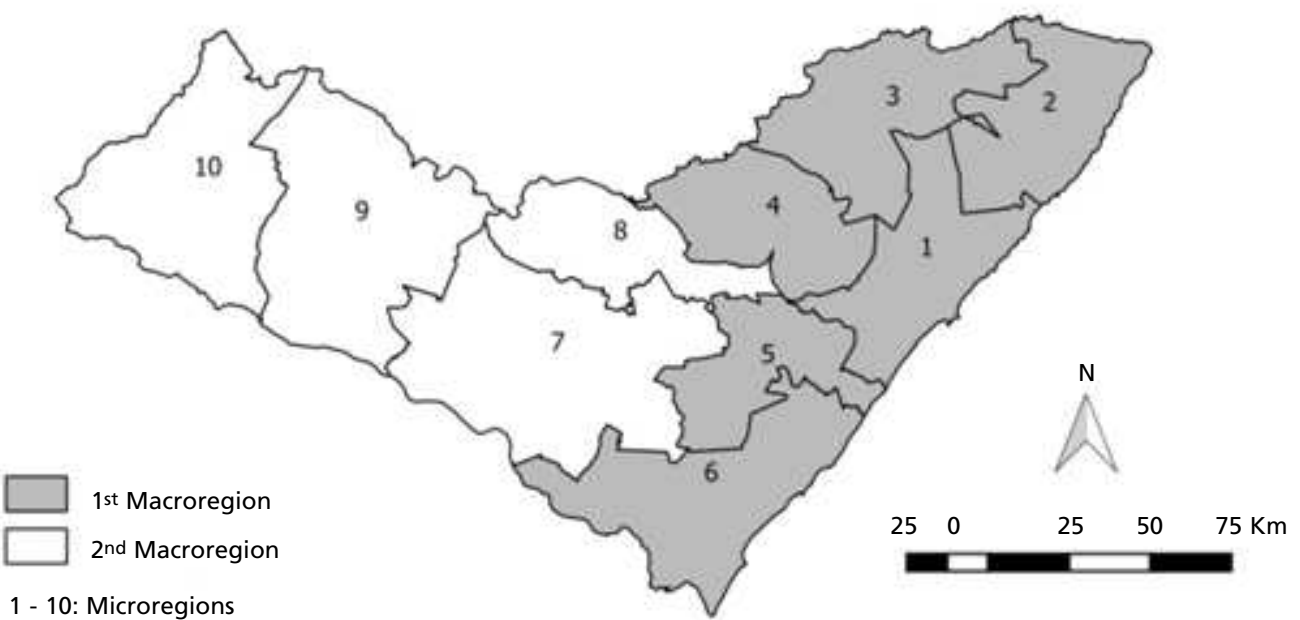

\begin{tabular}{|c|c|c|c|c|c|c|c|}
\hline \multirow[b]{2}{*}{ Territorial Unit } & \multicolumn{2}{|c|}{ Maternal deaths } & \multirow[t]{2}{*}{ MMR } & \multicolumn{4}{|c|}{ Jointpoint regression model 1996-2016 } \\
\hline & $\mathbf{n}$ & $\%$ & & APC & $\mathrm{Cl} 95 \%$ & $p$ & Classification \\
\hline \multicolumn{8}{|c|}{ Health Macroregion } \\
\hline $1^{\text {st }}$ & 366 & 62.46 & 45.22 & 3.1 & $1.4-4.8$ & $<0.001$ & Increasing \\
\hline $2^{\text {nd }}$ & 220 & 37.54 & 52.27 & 2.7 & $-0.7-6.1$ & 0.1 & Stationary \\
\hline \multicolumn{8}{|l|}{ Health Region } \\
\hline 1 st & 183 & 31.23 & 42.84 & 1.8 & $-0.7-4.4$ & 0.2 & Stationary \\
\hline $2^{\text {nd }}$ & 32 & 5.46 & 49.06 & 18.3 & $-8.6-53.3$ & 0.2 & Stationary \\
\hline $3 r d$ & 50 & 8.53 & 54.25 & 25.0 & $0.5-55.5$ & $<0.001$ & Increasing \\
\hline 4 th & 30 & 5.12 & 53.73 & 22.7 & $2.8-46.5$ & $<0.001$ & Increasing \\
\hline $5^{\text {th }}$ & 44 & 7.51 & 49.71 & 12.8 & $-1.6-29.2$ & 0.1 & Stationary \\
\hline 6 th & 27 & 4.61 & 33.58 & 12.3 & $-17.9-53.5$ & 0.4 & Stationary \\
\hline $7^{\text {th }}$ & 106 & 18.09 & 53.05 & 2.8 & $-0.5-6.3$ & 0.1 & Stationary \\
\hline $8^{\text {th }}$ & 21 & 3.58 & 34.83 & 6.5 & $-23.3-47.9$ & 0.7 & Stationary \\
\hline 9th & 56 & 9.56 & 56.74 & 8.4 & $-11.4-32.6$ & 0.4 & Stationary \\
\hline $10^{\text {th }}$ & 37 & 6.31 & 59.57 & -0.6 & $-27.8-37.0$ & 1.0 & Stationary \\
\hline State & 586 & 100.0 & 47.63 & 2.8 & $0.9-4.7$ & $<0.001$ & Increasing \\
\hline
\end{tabular}


Sociodemographic characterization of maternal deaths and Maternal Mortality Ratio (MMR), Alagoas, Brazil, 1996 to 2016.

\begin{tabular}{|c|c|c|c|c|c|c|c|c|c|}
\hline & \multicolumn{2}{|c|}{ Maternal deaths } & \multicolumn{2}{|c|}{ Live births } & \multirow[t]{2}{*}{ MMR } & \multicolumn{4}{|c|}{ Jointpoint regression model 1996-2016 } \\
\hline & $\mathrm{n}$ & $\%$ & $\mathrm{n}$ & $\%$ & & APC & $\mathrm{Cl} 95 \%$ & $p$ & Classification \\
\hline \multicolumn{10}{|l|}{ Age group (years) } \\
\hline $10-14$ & 5 & 0.85 & 16389 & 1.33 & 30.51 & - & - & - & - \\
\hline $15-19$ & 111 & 18.94 & 302631 & 24.60 & 36.68 & 5.4 & 2.6 to 8.2 & $<0.001$ & Increasing \\
\hline $20-29$ & 213 & 36.35 & 656651 & 53.37 & 32.44 & 3.4 & -0.4 to 7.3 & 0.1 & Stationary \\
\hline $30-39$ & 207 & 35.32 & 230492 & 18.73 & 89.81 & 0.1 & -2.3 to 2.5 & 0.9 & Stationary \\
\hline $40-49$ & 50 & 8.53 & 24211 & 1.97 & 206.52 & 2.3 & -19.1 to 29.3 & 0.8 & Stationary \\
\hline \multicolumn{10}{|l|}{ Skin Color/race } \\
\hline White & 75 & 12.80 & 187336 & 15.23 & 40.04 & 21.4 & -15.3 to 73.4 & 0.3 & Stationary \\
\hline Black & 19 & 3.24 & 12009 & 0.98 & 158.21 & 21.0 & 1.1 to 44.8 & $<0.001$ & Increasing \\
\hline Yellow & 1 & 0.17 & 4843 & 0.39 & 20.65 & -3.5 & -10.6 to 4.1 & 0.3 & Stationary \\
\hline Mixed & 334 & 57.00 & 819274 & 66.59 & 40.77 & 40.6 & 29 to 53.3 & $<0.001$ & Increasing \\
\hline Indigenous & 0 & 0.00 & 2949 & 0.24 & 0.00 & - & - & - & - \\
\hline Ignored & 157 & 26.79 & 203963 & 16.58 & - & & & & \\
\hline \multicolumn{10}{|l|}{ Schooling } \\
\hline None & 58 & 9.90 & 153282 & 12.46 & 37.84 & & & $-{ }^{a}$ & \\
\hline 1 to $<8$ years & 160 & 27.30 & 628088 & 51.05 & 25.47 & & & & \\
\hline 8 or more & 68 & 11.60 & 414068 & 33.65 & 16.42 & & & & \\
\hline Ignored & 300 & 51.19 & 34936 & 2.84 & - & & & & \\
\hline \multicolumn{10}{|l|}{ Marital status } \\
\hline Single & 264 & 45.05 & 499781 & 40.62 & 52.82 & & & $-{ }^{a}$ & \\
\hline Married & 184 & 31.40 & 350712 & 28.50 & 52.46 & & & & \\
\hline Widow & 8 & 1.37 & 2396 & 0.19 & 333.89 & & & & \\
\hline Legally Separated & 2 & 0.34 & 3201 & 0.26 & 62.48 & & & & \\
\hline Consensual union & 0 & 0.00 & 151452 & 12.31 & 0.00 & & & & \\
\hline Other & 19 & 3.24 & 0 & 0.00 & 0.00 & & & & \\
\hline Ignored & 109 & 18.60 & 222832 & 18.11 & 48.92 & & & & \\
\hline Total & 586 & 100 & 1230374 & 100 & 47.63 & & & & \\
\hline
\end{tabular}

MMR = Maternal Mortality Ratio; $A P C=$ Annual Percentage Change (annual percentage change for Portuguese) $\mathrm{CI} 95 \%=95 \%$ confidence interval; $p=$ Probability of significance; ${ }^{\text {a }}$ without enough data to calculate. 


\begin{tabular}{|c|c|c|c|}
\hline Variable & $\mathbf{N}$ & $\%$ & MMR \\
\hline \multicolumn{4}{|l|}{ ICD Group } \\
\hline Human Immunodeficiency Virus [HIV] disease. & 6 & 1.02 & 0.49 \\
\hline Pregnancyending in abortion. & 44 & 7.51 & 3.58 \\
\hline Edema, proteinuria and hypertensive disorders in pregnancy, childbirth and puerperium. & 154 & 26.28 & 12.52 \\
\hline Other maternal disorders predominantly related to pregnancy. & 19 & 3.24 & 1.54 \\
\hline \multicolumn{4}{|l|}{ Care provided to the mother for reasons related to the fetus and amniotic cavity and for } \\
\hline possible problems related to childbirth. & 40 & 6.83 & 3.25 \\
\hline Complications on labor and childbirth. & 141 & 24.06 & 11.46 \\
\hline Complications predominantly related to puerperium. & 123 & 20.99 & 10.00 \\
\hline Other obstetric conditions, not classified elsewhere. & 59 & 10.07 & 4.80 \\
\hline \multicolumn{4}{|l|}{ Categories with at least ten maternal deaths } \\
\hline Eclampsia & 76 & 12.97 & 6.18 \\
\hline \multicolumn{4}{|l|}{ Other diseases of the mother, classified elsewhere, but which complicate with pregnancy, } \\
\hline childbirth and puerperium. & 54 & 9.22 & 4.39 \\
\hline Abnormalities of uterine contraction. & 39 & 6.66 & 3.17 \\
\hline Postpartum hemorrhage. & 39 & 6.66 & 3.17 \\
\hline Other puerperal infections. & 35 & 5.97 & 2.84 \\
\hline Puerperal infection. & 30 & 5.12 & 2.44 \\
\hline Other complications on labor and childbirth, not classified elsewhere. & 29 & 4.95 & 2.36 \\
\hline Premature detachment of the placenta. & 28 & 4.78 & 2.28 \\
\hline Embolism of obstetric origin. & 27 & 4.61 & 2.19 \\
\hline Other complications of puerperium, not classified elsewhere. & 25 & 4.27 & 2.03 \\
\hline Gestational hypertension without any significant proteinuria. & 24 & 4.10 & 1.95 \\
\hline Unspecified maternal hypertension. & 22 & 3.75 & 1.79 \\
\hline Gestational hypertension with significant proteinuria. & 19 & 3.24 & 1.54 \\
\hline Otherobstetric traumas. & 16 & 2.73 & 1.30 \\
\hline Ectopicpregnancy. & 14 & 2.39 & 1.14 \\
\hline Unspecified abortion. & 10 & 1.71 & 0.81 \\
\hline Complicated labor and childbirth by intrapartum hemorrhage, not classified elsewhere. & 10 & 1.71 & 0.81 \\
\hline Other observed categories $(n=31)$ & 89 & 15.19 & 7.23 \\
\hline
\end{tabular}

Obstetric cause

Direct obstetric maternal death

Indirectobstetric maternal death

Unspecified obstetric maternal death

MMR = Maternal Mortality Ratio 


\section{Figure 2}

Spatial modeling of maternal deaths in Alagoas, Brazil, 1996 to 2016.

a) Classification of the cities according to the number of maternal deaths

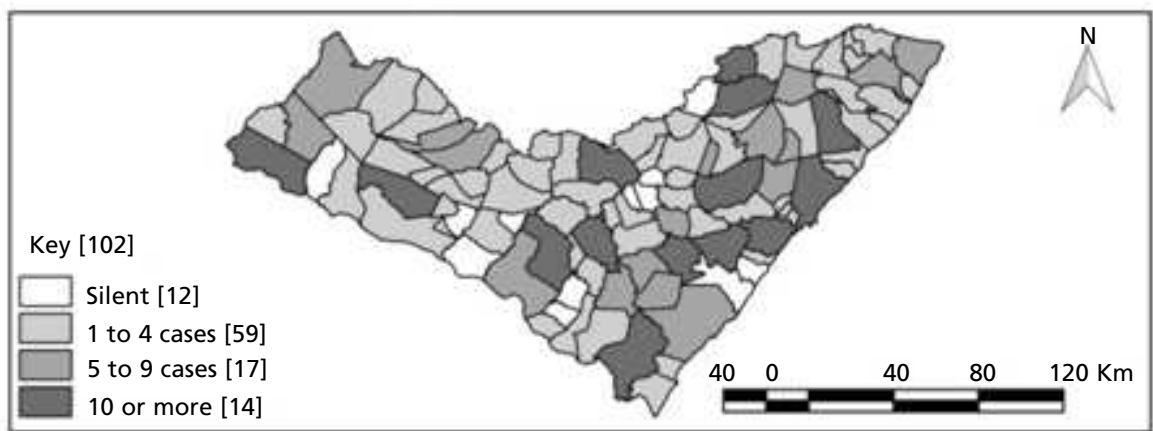

b) Gross maternal mortality ratio

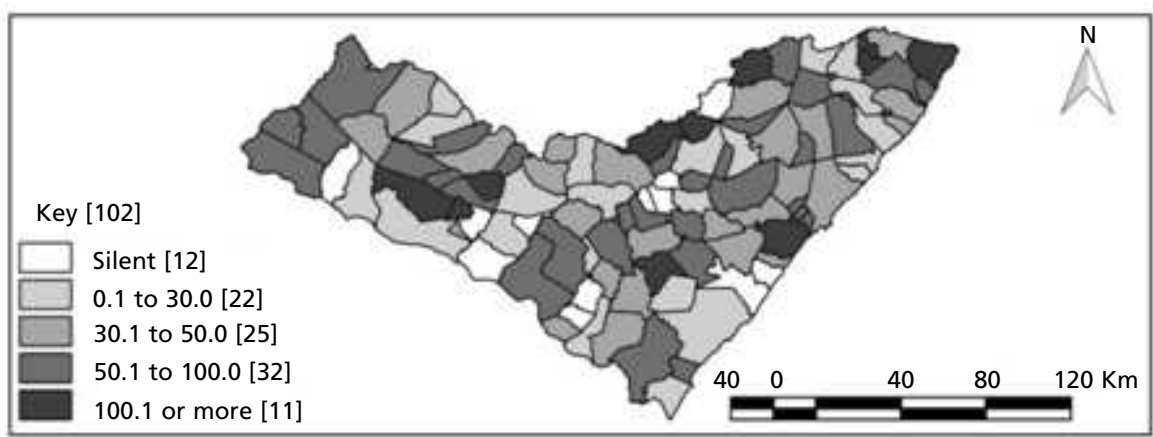

c) Smooth maternal mortality ratio

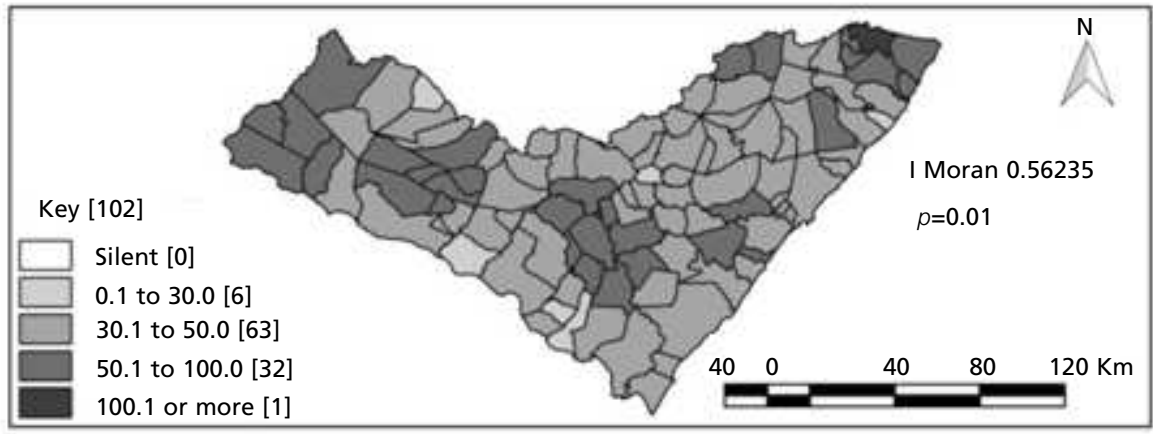

d) Moran map smooth maternal mortality

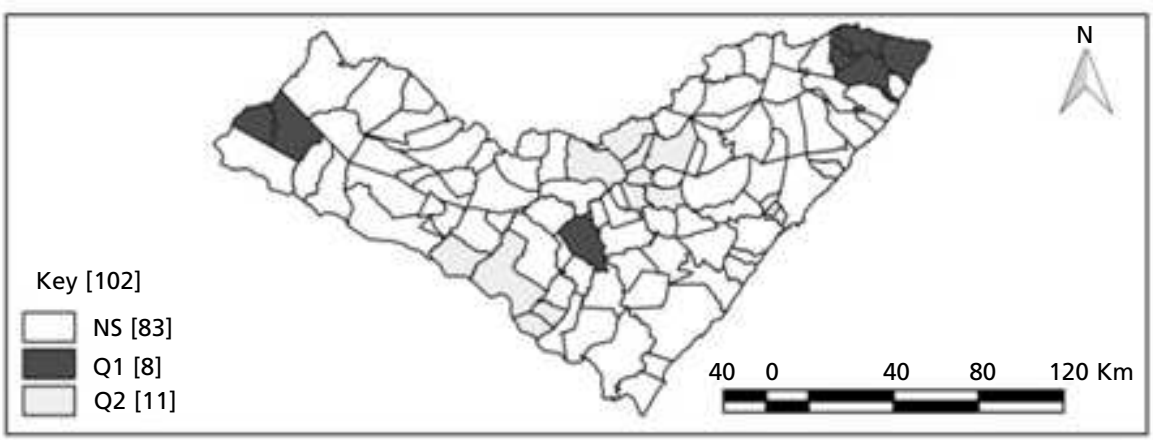

NS= Non significant 
Figure 3

Bivariable spatial autocorrelation between the maternal mortality ratio and social indicators, Alagoas, Brazil, 1996 to 2016.

a) Social Vulnerability Index - General

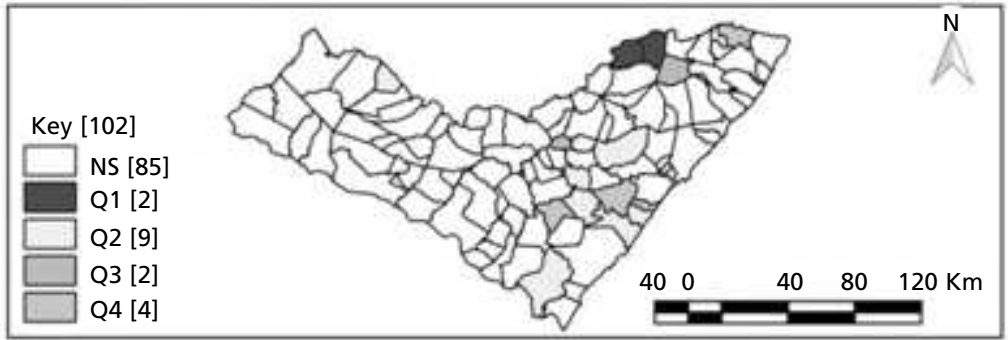

b) Social Vulnerability Index - Urban Infrastructure

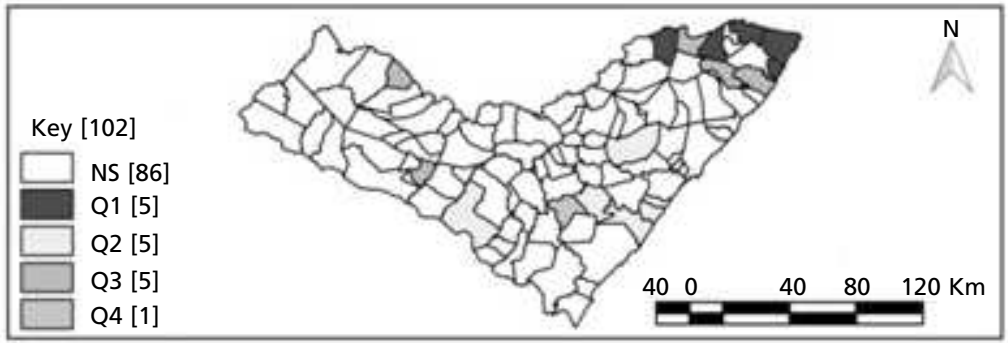

c) Social Vulnerability Index - Human Capital

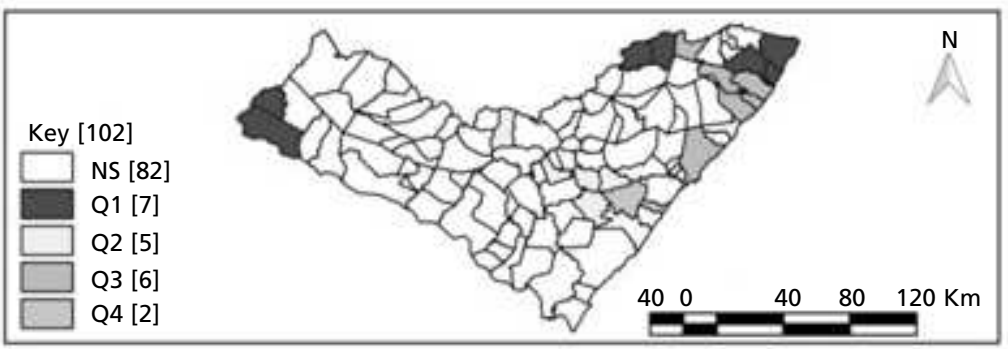

d) Social Vulnerability Index - Income and Work

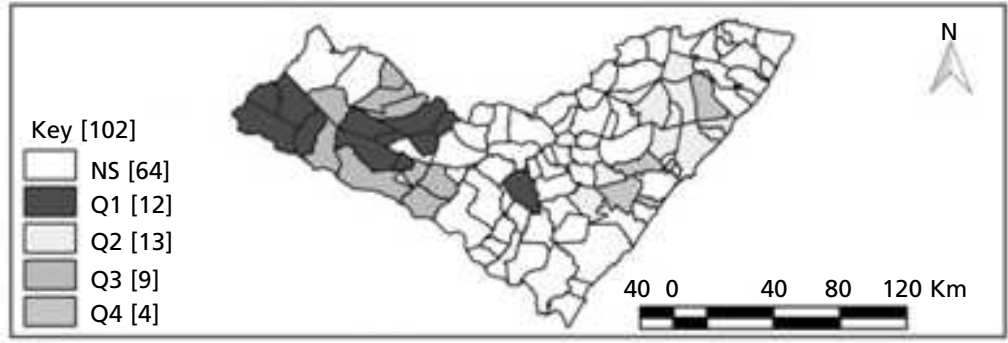

e) Gini's Index (Income inequality)

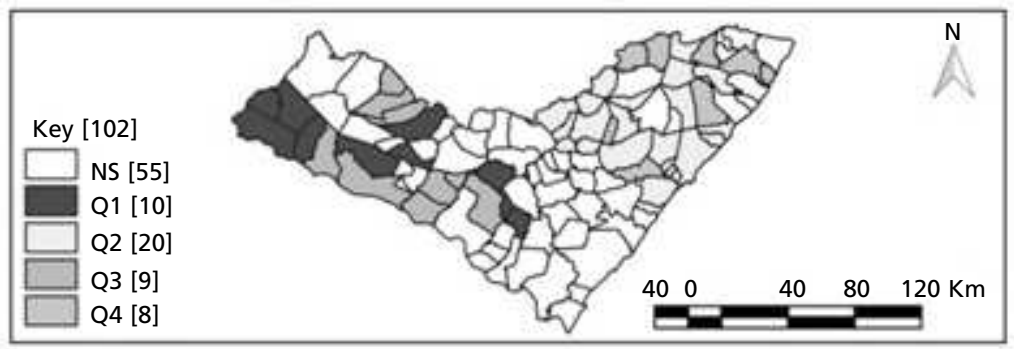

NS= Non significant. 


\section{Discussion}

This study analyzed the spatial-temporal dynamics on maternal mortality in the State of Alagoas (19962016) and the spatial relation with social vulnerability and income inequality. Maternal mortality is a public health problem that affects mainly underdeveloped and developing countries, such as Brazil, in which the sociodemographic characteristics reflect risk factors. 15 The profile observed in Alagoas is in line with the literature, 16 characterized by the predominance of the age group 20-29 years old (in numbers and percentages), race / black and mixed skin color and low schooling.

Black and mixed skin color women are the groups that are most vulnerable to maternal death. A study carried out in Mato Grosso, involving 219 deaths between 2000 and 2006, showed that the relative risk of women who died due to maternal causes was 7.4 times higher in black women when compared to ethnicity/white race.16 In Minas Gerais, $59 \%$ of the maternal deaths between 1996 and 2008 were non-white women, 17 corroborating this present study. Ethnic differences are associated with social inequalities and adverse social insertion condition, characterized by little or no access to obstetric care services. 16

In the context of social vulnerability, low schooling is another striking feature. In this study, considering only the registrations whose schooling level was concluded, $76.22 \%$ had less than eight years of schooling and the MMR decreased following the increase in education, similar to that observed in Paraná (64.3\%). 17 The schooling level has a double effect on mortality: i) education determines the cultural profile and the behavior related to healthcare ${ }^{16}$ and ii) and reduces the degree of social vulnerability, which is inversely proportional to access consumer goods and services, including health. 18

Alagoas is the State with the lowest Índice de Desenvolvimento Humano (IDH) (Human Development Index) in Brazil (IDH=0.631) and has about $96.10 \%$ of the cities in high or extremely high social vulnerability. ${ }^{10,11}$ The bivariable spatial correlation identified common priority areas related to urban infrastructure, human capital and income and work (including income inequality expressed by the Gini Index). In Brazil and Colombia, income inequality contributed to $23.40 \%$ in the difficulty of accessing specialized services and $37.20 \%$ to postnatal care, increasing the risk of maternal deaths. 19

Even with the implementation of the Rede Cegonha (Stork Network) (2011/2012), which repre- sents one of the most important public policies for the qualification of maternal and child care in Brazil, is responsible for the decline in maternal deaths, 20 Alagoas did not show a temporal change in the mortality, although the rate decreased from $59.09 / 100$ thousand LB (2010) to 51.90/100 thousand LB (2016). This is to show that in vulnerable areas, the implementation of isolated health policies is not enough, but broader ones are needed that can impact on social determinants, by reducing existing pragmatic inequalities.

In 2014 , about $99 \%$ of the women had at least one prenatal visit, in $76 \%$ of the first visit occurred before 16 weeks and $73 \%$ had six or more visits. 21 Even so, the quality of the program or the lack of adherence to the actions undermines its effectiveness. In 2018, in Brazil, in the North Region obtained the "worst adjustment" in the provision of services for prenatal care $(51 \%)$ in the country (i.e., organizational analysis on services, quality of care and clinical care offered), followed by the Midwest (48\%), the Northeast (44\%) and the Southeast (43\%), indicating that the country needs to expand its investments in maternal care. 21

In Maceió, the capital of the State, an investigation carried out in 2016 showed that $74 \%$ of the pregnant women had difficulties in performing prenatal exams, with the scheduling and receiving the results were the main difficulties reported.22 This fact indicates that the capital faces systematic difficulties in guaranteeing the quality of care offered to the maternal and child population, especially in the primary health care component. 23 In the countryside of the State, where the context of vulnerability is more intense and the cities face more difficulties (scarcity of financial resources, lack of human capital and precarious health services), the situation can be even more severe, since mortality rates are higher. The $9^{\text {th }}$ and $10^{\text {th }}$ health regions, located in the Outback lands of the State, for example, had the highest mortality rates.

Maternal deaths in Alagoas resulted mainly from hypertensive disorders during pregnancy, with eclampsia as the main cause, similar to the pattern observed in the country. ${ }^{24}$ In 2017, in Latin America, these disorders accounted for $41 \%$ of the maternal deaths. 25 The high occurrence of eclampsia is related to the poor quality of care, representing a potentially preventable cause. 10,26

Direct obstetric causes accounted for $87.71 \%$ of maternal deaths in Alagoas, corroborating studies carried out in Bahia (62.8\%)27and in the city of Barbacena, Minas Gerais (82.75\%). 28 This group of causes is more prevalent in pregnant women with 
greater social vulnerability and derives from complications related to the pregnancy-puerperal cycle, due to poor care during pregnancy, childbirth or puerperium. ${ }^{27}$

The women's healthcare network in Alagoas is structured so that in the ten health regions (HR) there are primary care services and the usual risk reference centers, except in the $4^{\text {th }}$ and 9 th HR. While the highrisk reference centers are located only on the $1^{\text {st }} 7^{\text {th }}$ and 9 th HR. In the Moran Map, it was observed that the cities located in the $2^{\text {nd }}$ and $10^{\text {th }} \mathrm{HR}$ were a priority. However, in the region, there are basic care services for pregnant women, indicating that there are weaknesses in the network. ${ }^{28}$ In an investigation carried out in Espírito Santo, it was shown that despite the good coverage of the Rede Cegonha (Stork Network) in one of the HR, its malfunction caused the loss in the quality of care, aggravating the risks mainly in low-income pregnant women.29 Access to health services, quality of care and early identification of possible complications are related to increased risk during pregnancy and its unfavorable outcome. 28

Even considering methodological care, this study has limitations, among which the use of secondary data stands out, whereas quality has been questioned. The operational capacity of the surveillance system

\section{References}

1. Martins ACS, Silva LS. Epidemiological profile of maternal mortality. Rev Bras Enferm. 2018; 71 (sup.1 1): 725-31.

2. Brasil. Ministério da Saúde. Departamento de Informática do SUS (DATASUS). Óbitos maternos por ano do óbito segundo região: período: 1996-2016. 2019 [acesso jun 2019]. Disponível em: http://tabnet.datasus.gov.br/cgi/ tabcgi.exe?sim/cnv/mat10uf.def

3. Brasil. Ministério da Saúde. Manual dos comitês de mortalidade materna. Brasília, DF; 2009.

4. Brasil. Ministério da Saúde. Departamento de Informática do SUS (DATASUS). Razão de mortalidade materna - C.3 (taxa de mortalidade materna, coeficiente de mortalidade materna). 2018 [acesso dez 2018]. Disponível em: http://tabnet.datasus.gov.br/tabdata/LivroIDB/2edrev/c03.p df

5. Centro Regional de Informação das Nações Unidas (UNRIC). Objetivo de desenvolvimento do milênio 5 melhorar a saúde materna. Departamento de Informação Pública da ONU - DPI/2517E. 2010 [acesso jul 2019] Disponível em: https:/www.unric.org/pt/objectivos-dedesenvolvimento-do-milenio-actualidade/27669-objectivo5-melhorar-a-saude-materna is one of the most important determinants of the quality of registered in the health information systems. The Northeast is the region with the highest underreporting cases in the country, which can compromise the reliability of the analyses.

In this study, the demographic profile was characterized by the predominance of young women (although MMR increases with age), with mixed skin color and low schooling. Direct causes and eclampsia made up the clinical profile. The trend was increasing in the State, with spatial-temporal inequality and correlation with social vulnerability and income inequality. The identification of priority areas can contribute to the planning, monitoring and targeting of the interventions

\section{Authors' contribution}

Duarte SEM, Santos ET, Souza CDF were responsible for the study design, performed the data acquisition and analysis, participated in the writing, interpretation of the results and review of the article; Araújo MDP, Machado MF, Correia DS, Fonseca LGA, Silva SM participated in the writing, interpretation of the results and review of the article. All authors approved the final version of the manuscript.

6. Brasil. Ministério da Saúde. Departamento de Informática do SUS (DATASUS). Nascimento por residência da mãe por ano do nascimento segundo região: Período: 2015. 2019 [acesso jul 2019]. Disponível em: http://tabnet.datasus. gov.br/cgi/tabcgi.exe?sinasc/cnv/nvuf.def

7. Organização das Nações Unidas No Brasil (ONUBR). Agenda 2030. 2015 [acessado em jul 2019]. Disponível em: https://nacoesunidas.org/pos2015/agenda2030/

8. Brasil. Ministério da Saúde. Rede cegonha: gravidez, parto e nascimento com saúde, qualidade de vida e bem-estar. Brasília, DF; 2013.

9. Brasil. Ministério da Saúde. Portaria GM n 1.459 , de 24 de junho de 2011: Institui no âmbito do Sistema Único de Saúde a Rede Cegonha. Brasília, DF; 2011.

10. IBGE (Instituto Brasileiro de Geografia e Estatística). Brasil/ Alagoas. Censo 2010. 2010 [acesso jul 2019]. Disponível em: https://cidades.ibge.gov.br/brasil/al/ panorama

11. IPEA (Instituto de Pesquisa Econômica Aplicada). Atlas da vulnerabilidade social nos municípios brasileiros. Brasília, DF; 2015.

12. Kim HJ, Fay MP, Feuer EJ, Midthune DN. Permutation tests for joinpoint regression with applications to cancer rates. Stat Med, 2000; 19 (3): 335-51. 
13. Gelman A. Bayesian data analysis. London; New York: Chapman \& Hall; 1995.

14. Druck S, Carvalho MS, Câmara G, Monteiro AMV. Análise espacial de dados geográficos. Brasília: EMBRAPA; 2004.

15. Biano RKC, Souza PCB, Ferreira MBG, Silva SR, Ruiz MT. Mortalidade materna no Brasil e nos municípios de Belo Horizonte e Uberaba, 1996 a 2012. Rev Enfer CentroOeste Min. 2017; (7): e1464.

16. Teixeira NZF, Pereira WR, Barbosa DA, Vianna LAC. Mortalidade materna e sua interface com a raça em Mato Grosso. Rev Bras Saúde Matern Infant. 2012; 12 (1): $27-$ 35 .

17. Faria DR, Sousa RC, Costa TJNM, Leite ICG. Mortalidade materna em cidade-polo de assistência na região Sudeste: tendência temporal e determinantes sociais. Rev Med Minas Gerais. 2012; 2 (1): 18-25

18. Souza KV, Almeida MRCB, Soares VMN. Perfil da mortalidade materna por aborto no Paraná: 2003-2005. Esc. Anna Nery Rev Enferm. 2008; 12 (4): 741-9.

19. Medeiros LT, Sousa AM, Arinana LO, Inácio AS, Prata MLC, Vasconcelos MNG. Mortalidade materna no estado do Amazonas: estudo epidemiológico. Rev Baiana Enferm 2018; (32): e26623.

20. De La Torre A, Nikoloski Z, Mossialos E. Equity of access to maternal health interventions in Brazil and Colombia: retrospective study. Int J Equity Health. 2018; 17 (1): 43.

21. Dias MAB, Domingues RMSM, Schilithz AOC, Pereira MN, Diniz CSG, Brum IR, Martins AL, Filha MMT, Gama SGN, Leal MC. Incidência do near miss materno no parto e pós-parto hospitalar: dados da pesquisa Nascer no Brasil. Cad Saúde Pública. 2014; 3 (Supl.): 169-81.

22. Cavalcante KOR, Santos AA, Lúcio IML, Silva LMO, Melo DAS, Jacintho KS. Exames de rotina no pré-natal solução ou problema? Rev Enferm UFPE. 2016; 10 (Supl. 3): $1415-22$
23. Pereira GT, Santos AAP, Silva JMO, Nagliate C. Epidemiological profile of maternal mortality due to hypertension: situational analysis of a northeastern state between 2004 and 2013. Rev Fund Care. 2017; 9 (3): 653-58.

24. Bailey PE, Andualem W, Brun M, Freedmam L, Gbangbade S, Kante M, Keyes E, Libamba E, Moran AC, Mouniri H, Joud DO, Singh K. Institutional maternal and perinatal deaths: a review of 40 low and middle income countries. BMC Pregnancy Childbirth. 2017; 17: 295.

25. Giordano JC, Parpinelli MA, Cecatti JG, Haddad SM, Costa ML, Surita FG, Pinto E, Silva JL, Sousa MH. The burden of eclampsia: results from a multicenter study on surveillance of severe maternal morbidity in Brazil. PLoS One. 2014; 9 (5): e97401.

26. Coelho VC, Andrade MS, Sena CD, Costa LEL, Bittencourt IS. Caracterização dos óbitos maternos em três regiões de saúde do centro-norte baiano. Cogitare Enerm. 2016; 21 (1): $1-8$.

27. Carvalho LRO, Fonseca LML, Coelho MTC, Machado MGS, Carvalho MB, Vidal CEL. Mortalidade de mulheres em idade fértil entre 1998 e 2012 na microrregião de Barbacena. Rev Interd Est Experi. 2016; 8 (n.único): 15-22.

28. Secretaria de Estado da Saúde - SES. Governo de Alagoas. Plano estadual de saúde. 2016-2019. Alagoas, 2016.

29. Martinelli KG; Neto ETS; Gama SGN; Oliveira AE. Adequação do processo da assistência pré-natal segundo os critérios do Programa de Humanização do Pré-Natal e Nascimento e Rede Cegonha. Rev Bras Ginecol Obstet. 2014; 36 (2): 56-64.

Received on September 3, 2019

Final version presented on December 11, 2019

Approved on January 27, 2020 